\title{
Examination of Affordable Housing Policies in India
}

\author{
Anindo Sarkar \\ Udayan Dhavalikar \\ Vikram Agrawal \\ Sebastian Morris
}

W.P. No. 2016-03-33

March 2016

The main objective of the working paper series of the IIMA is to help faculty members, research staff and doctoral students to speedily share their research findings with professional colleagues and test their research findings at the pre-publication stage. IIMA is committed to maintain academic freedom. The opinion(s), view(s) and conclusion(s) expressed in the working paper are those of the authors and not that of IIMA.

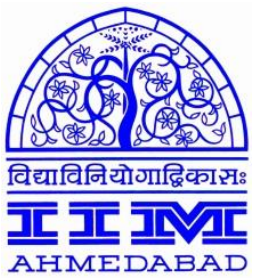

\author{
INDIAN INSTITUTE OF MANAGEMENT \\ AHMEDABAD-380 015 \\ INDIA
}




\title{
Examination of Affordable Housing Policies in India
}

\author{
Anindo Sarkar \\ Udayan Dhavalikar \\ Vikram Agrawal \\ Sebastian Morris ${ }^{1}$
}

\begin{abstract}
In this paper we critique the Government of India's programmes for affordable housing in India, namely the Rajiv Awas Yojana and Housing for All 2022. We analyse the efficacy of these policies in being able to provide thee sections of the population who are unable to avail housing from the formal market, both through direct support and most importantly in addressing the many distortions that have made the housing unnecessarily expensive, while taking away much of the value to consumers. We argue that while these programmes and policies are a major advancement over the previous approaches, they do not fully exploit the potential that is there in increased FSI, sensitivity of low cost housing development to exploiting locational value appropriately, to use of government land judiciously, to the reform of titles and squatter rights, and to more efficient land use changes. They are also constrained by an inability to distinguish between what the markets can be coaxed to deliver and where state intervention becomes necessary.
\end{abstract}

${ }^{1}$ Emails: Anindo Sarkar p14anindos@iima.ac.in, Udayan Dhavalikar p14udauand@iima.ac.in, Vikram Agrawal p14agrawalvikram@iima.ac.in and Sebastian Morris morris@iima.ac.in 


\section{Examination of Affordable Housing Policies in India}

\section{INTRODUCTION}

Housing for very long in the post-independence period has had low priority. The logic of planning with its material balances implied that important materials like steel and cement whose outputs were sought to be expanded greatly, had priority for use in the capital goods and infrastructure sectors, since the argument was made that the higher the growth rate of production of capital goods in a closed economy the ultimate growth rate of the economy would be higher. Being a final goods sector whose consumption if restricted would also enhance the supply of savings outflow from the household sector. Hence the state owned development finance institutions (DFIs) and the banks were restricted in lending for house construction. Indeed the HDFC was able to lend finance to households only because of its claim that it was not using public money (taxes or deposits) but was raising capital in the markets ${ }^{2}$. The same argument allowed Reliance to bypass the Textile Policy of 1956 which otherwise constrained all organised sector textile industry. It was only in 1980s with HDFCs operations and later with the LICs operations that finance to fund house construction could take place on any meaningful scale. HUDCO's focus was more on urban infrastructure and financing town and government authorities and parastatals to construct real estate other than housing and only marginally in housing.

All that is history with the liberalisation brought in by the Narashima Rao government in 199192 /92-93, and thereafter which freed banks and financial institutions (FIs) to make loans to individual households for house construction and purchases, and to builders to finance their construction. Over the dream run of the Indian economy from 2003 to 2008, the very high growth of over $8.5 \%$ per annum happened on the back of large investments in housing.

The problem of affordable housing was a seemingly a government priority as evident in the rhetoric of many programmes of housing for the poor, the so called LIG housing areas in the master plans of many large and medium sized cities. LIG housing has absorbed significant public resources, but has thus far proved to be quite inadequate to address the problem of affordable housing. A few interesting developments of using private firms to build houses for the poor which the government then allocates have a better record in terms of quality and occupancy such as by the AP Housing Board have not been followed on the scale and quantum required to overcome the problem.

Today when many regions hope to revive housing to lift the economy out of the recession, the problem of affordable housing has no ideological or doctrinaire difficulties, nor are there any significant limitations that come from the financing side. In this paper we examine the Government of India's programmes for affordable housing in India, namely the Rajiv Awas Yojana and Housing for All 2022, and bring out the core finding that in ignoring the structural limitations that arise out of the assumptions of urban planning, transport and infrastructure design in towns and cities, severe distortions with regard to land use and allocation in the country, besides the limitations in the design of these specific policies, the effectiveness in enhancing affordability has been very limited. Scale and scope also continue to be limiting especially when one recognises that affordable housing in late industrialising economies have come out of massive government commitment through public housing and measures to reduce the cost especially of land with high locational value.

\footnotetext{
${ }^{2}$ The contention is obviously not correct when considered holistically.
} 


\section{CONTEXT}

India is witnessing rapid urbanisation where the growth in the urban population is by almost $3 \%$ every year as a result of migration from small towns and villages (NSSO,2007) . Expanding urban population has thus made increasing the housing supply necessary. For a variety of reasons, the growth in demand is not being met by supply of housing units resulting in housing shortage in urban areas. The growth per se is not unusual as if often made out to be since rapid urbanisation with the economic transformation is observed without almost no exception. $^{3}$

The housing "shortage" figures generally referred to in India by the government, and repeated by others is actually needs based. The housing shortage that is based on actual effective demand not being met has usually been missed in the discussions on housing. A UK Government paper on Estimating Housing Needs 2010, (Dept. for Communities and Local Government, 2010) reported the following as the major difference between the need and demand based shortage, "Need based - Shortfall from certain normative standards of adequate accommodation. Demand based - Quantity and quality of housing which households will choose to occupy given their preferences and ability to pay (at given prices)." Demand based estimation itself would not be as robust as in the case of goods and services that do not involve market failure. Land markets suffer from the hold -out problem, specific values, and values arsing out the use of other lands. Thus the aspect of locational value (which arises out of the location of land relative to other lands and on the economic activities on these other lands) also prevents the market from efficient use and allocation Some of these such the hold out problem in aggregating land, can be overcome, but others can only be mitigated by regulation. Regulation when improper can often compound the problem and add further to the perversities in the market. This is the case in India. (Morris, Sebastian and Ajay Pandey 2010) . Therefore the cost price of housing for the same size and locational value can vary greatly so that the demand based estimation is meaningful only if the supply prices reflect true costs and scarcities, and not high costs (as they do in India) on account of perversities in regulation, land allocation, etc.

The Technical Group on Urban Housing Shortage for the Twelfth Five Year Plan (2012 - 17) defines housing shortage as comprised of the following components:

- Excess of households over the acceptable housing stock (people living in informal properties)

- Number of extra households needed due to congestion

- Number of extra households needed due to obsolescence

- Number of kutcha households that must be upgraded

The above classification is need based perspective of housing shortage alone and ignores the housing requirements from the demand. It other words it is not the effective demand for

3 The conceptual basis for the same otherwise well-known, needs emphasis in the Indian debate on the same since many believe an alternative path of low urbanization and economic development is possible for India by "providing infrastructure in rural areas". PURA is a programme with much resources that makes this airy assumption. It is well known that only primary sectors depend upon land thereby spreading out humans. As increasingly the value added arises from production of "produced goods" and of services which require humans to be in close proximity to intensely and richly interact and communicate with each other, the basis of agglomerations and urbanization is clear enough. 
housing. By this definition, the total need based housing shortage in the country is around 19 million units as per census 2011. (Appendix I)

The housing market can be considered as being of two types, formal and informal. The formal housing units have to meet a certain strict criteria set by the Government (Appendix VII). In reality, however, many of these criteria are systematically violated owing to their inflexibility and perhaps even "unviability". The informal market on the other hand, is outside the purview of the law and accordingly most of them do not conform to even basic standards necessary, and perhaps otherwise possible to maintain a basic lifestyle. Apart from such dwellings a certain percentage is completely homeless. However, this percentage is very small $(\sim 3 \%)$ (Appendix I). Those people who are unable to afford housing in the formal market use the informal "markets" to stay in bastis, chawls, some of which could be "squatter" or "illegal settlements" especially in the larger cities.

The Indian Government has formulated many policies for housing especially since the late eighties including the National Housing Policy of 1988 (Appendix XI). Additionally, many bodies like the National Housing Bank (NHB) and Housing \& Urban Development Corporation (HUDCO) had also been created to facilitate the implementation of such policies. The first policy specific to urban housing was the National Urban Housing and Habitat policy in 2007 (Ministry of Housing and Urban Poverty Alleviation, 2007). It focused on affordable housing as a key objective for sustainable urban development. Following this, many programmes specific to affordable housing have since been incorporated:

- Jawaharlal Nehru National Urban Renewal Mission (MoHUPA, 2015a) : It aimed to construct 1.5 Million houses for the urban poor in the mission period (2005-2012) in the 65 mission cities. Two policies under JNNURM targeted housing. Integrated Housing and Slum Redevelopment Programme is a direct housing policy measure under JNNURM. Basic Services for the Urban Poor (BSUP) aims at providing entitlements such as security of tenure, affordable housing, and services such as water, sanitation, health and education and social security to low-income segments

- Affordable Housing in Partnership (AHP)(MoHUPA, 2013): A market solution based approach by involving private players.

- Rajiv Awas Yojana(MoHUPA, 2012a): This programme aimed at providing affordable housing to the urban poor.

- On May 2015, Rajiv Awas Yojana (RAY) was rolled over into the Housing for All (HFA) by 2022 policy. This report analyses the RAY and HFA 2022 policies after developing a framework for sustainable policies for addressing the problem of affordable housing.

\section{MARKET AND GOVERNMENT IN AFFORDABLE HOUSING}

Conceivably the solution to the problem of urban housing could be visualised via a two pronged approach. The first step would be to make formal housing cheaper, since it is well known that house costs are driven up by unaddressed or perversely addressed market failure, the "cost of improper regulation" and of poor governance. These happen especially through land whose "prices" embody the cost of regulatory failures, and hurdles and restrictions in land use. A key component of this entails reducing the land cost per unit of built up area. In India, restricted land use policies, lower FSI, land transfer restrictions (increasing the transaction costs), and other such policies have led to an increase in the land prices. Appropriate policies can significantly reduce the cost per built up area and allow more people to avail housing through the formal market itself. (Morris and Pandey 2010). 
There however, will be a certain section of the population who even with the most optimal regulation of housing and of land and its use, would still not be able to afford the basic dwelling unit.. These households being poor ought to be supported by the Government if they are to have access to basic housing ${ }^{4}$. The cost outlay for such programmes will be much smaller than they are presently if the policies to make the market efficient are already been put in place. Otherwise, without this reform, the fiscal cost would be very large for even a modicum of coverage of the poor, and any universal coverage would be be out of question (Appendix V).

The government through its various schemes is trying to to enhance the supply of affordable housing to the urban and rural poor. An initial calculation (Appendix V) reveals that the expenditure in meeting the total housing shortage works out to a whopping $9 \%$ of India's GDP without taking into account the land costs, and to 19\% of India's GDP after taking into account the land "costs". In any social cost benefit analysis land costs are not relevant -except in so far as the value of the land lost from the use of land in agriculture has to be recognised.

This means that if that government has to spend $2 \%$ of its annual GDP on affordable housing, to be able to provide housing for everyone in the next 5 years. This is a number which may look financially feasible and it may seem to be a plausible solution. However, there are a number of factors which make such a large deployment of fiscal resources infeasible:

- The FY 2016 budget outlay for Ministry of Housing and Urban Poverty Alleviation stands at ₹ $15794 \mathrm{cr}$. (Ministry of Finance, 2015a) This is close to $0.13 \%$ of the GDP. Hence, an annual expenditure of $2 \%$ of GDP is a very high jump. This will be difficult to achieve politically and economically.

- Without reform of the land and regulatory environment if houses are built without reference to the optimality of the locations where they arise such "affordable housing" development would take place only in the fringes and areas far from current urban places, where people who have work in the cities and need to access central places would not prefer to stay, the locational values being too poor.

\section{CURRENT REACH OF THE FORMAL MARKET}

To estimate the demand for housing - conditional on the cost-, the income and income distribution would have to be known. Although income and its distribution ${ }^{5}$ vary across regions we consider the case of Ahmedabad. We shall consider the present property prices and income distribution in Ahmedabad to illustrate the reach of the formal market.

\footnotetext{
${ }^{4}$ Access to basic housing becomes a necessity if access to water and sewerage systems have to be universal. And there are huge social losses (on account of disease) when these services are even marginally less than universal. Moreover at modest level they become a "right" certainly at this stage of development in India - if the right to human dignity has to be ensured. 5 The highly detailed data on consumption expenditure from the National Sample Survey Organisation being person weighted rather than income weighted is not suitable. These when used directly as most studies do result in very low income inequalities for India, which is hardly the case. Hence other sources even if not based on very large samples are required.
} 
Considering an average price of ₹ 4700 / sq ft in Ahmedabad (Refer Appendix II), the EMI for a basic dwelling of $250 \mathrm{sq} \mathrm{ft}$ comes to around ₹ 13,000 (Appendix III). Assuming a savings rate $^{8}$ of $32 \%$ this translates into a monthly income of $₹ 40,000$.

As per the Appendix IV, the percentage of households that can afford a minimum size dwelling unit of $250 \mathrm{~m}^{2}$ is only $19 \%$ in Ahmedabad. Hence, it can be said that the current formal housing prices are prohibitively huge which leads people to search for housing through the informal market.

If the cost/sq ft can be reduced to ₹ 2500 through a variety of measures (see below) that include reducing the distortions in land markets, regulatory reform including allowing high FSI/FAR and removing the vast regulatory rents, the reach of the formal housing market can easily be doubled (Appendix V Table 3)

\begin{tabular}{|l|c|}
\hline Household Monthly Income & 40,000 \\
\hline Household Annual Income & $4,80,000$ \\
\hline$\%$ of Households with Income $>4,80,000$ & $19 \%$ \\
\hline
\end{tabular}

Assuming uniform distribution of household income distribution between the income range of $2,76,000$ and $13,80,000$

\section{REASONS FOR LOW REACH OF THE FORMAL MARKET ${ }^{6}$}

Government policies have significantly caused supply problems. These policies are indirectly responsible for increasing the cost of housing. The ways in which the government affects supply are as follows:

\section{Low FAR/FSI}

The Floor to Area Ratio (FAR or FSI) is defined as the ratio of maximum floor area allowed for construction to the land area on which the building is constructed. The FAR is an important parameter in defining the height of the buildings and hence, has a major potential to affect the housing supply. Additional independent height restrictions, restrictions due to "heritage" places nearby etc, which may constrain the FAR are sometimes in place as well.

The FAR is kept low in the Indian cities against the backdrop of "limiting" population density and "avoiding" congestion. However, this intention has not been fulfilled by the policy as despite keeping the FAR low, the population density has not reduced as the number of people per unit constructed area is very high.

New York with an FSI of 15 (Appendix VIII) has a population density of 4,000 per sq $\mathrm{km}$ whereas Mumbai with an average FSI of 1.33 has a population density of 20,000 per sq km.

The impact of lower FSI has been to curtail the housing supply over the years. This has led to a situation where the property prices have shot up beyond reasonableness. Mumbai with an FSI of 1.33 has one of the most expensive property rates in the world, which is very much because of the lower FAR. This lowering of land supply in the prime locations of the city leads to horizontal expansion of the city which in turn leads to an increase in commuting cost and increase in energy consumption which is a load on the economy. As the families generally

${ }^{6}$ The conceptual basis for the discussions herein are from Morris, Sebastian and Ajay Pandey (2009) and Morris, Sebastian and Ajay Pandey (2010). 
want to avoid moving outside the centre of the city, they stay in congested conditions with multiple families living inside the same house. Hence, the population density does not go down despite the lower FAR.

An increase in FAR is the way forward for the major Indian cities. Increased FAR will have the direct impact of increasing the housing supply leading to lowering of housing prices and making it affordable to many people who currently cannot afford.

The arguments against a higher FAR basically majorly argue that our prime locations cannot serve the greater demand and pressure that will be put on the existing systems, such as the increased demand on the road and railway transportation systems, water and sewerage systems, sanitation system and electricity system. The major fallacy in this argument is that they do not consider the current congestion and already high population density in these areas which will not increase significantly by increasing the FARs. An increase in FAR will not (and cannot) increase the population in absolute terms and also will have minimal impact in increasing the population density (people will not settle in a particular location only because it has a higher FAR). (Morris, and Pandey, 2010).

Therefore, increasing the FAR is an important step in decreasing the cost of the land component in housing and urban infrastructure, and such policies are highly recommended and are also in the nature of low hanging fruits. Suddenly increasing the FAR/FSI would put windfall gains into the hands of property and land owners where this increase is allowed. However this cannot be an argument against increase. There are ways to combine increase with transfer of development rights (TDRs), auction of FSI, having buildable FSI based on FSI procured from others not using their FSI, and intervention in the TDR markets by which rapid convergence to socially optimal land use and to optimal densities is possible,. (Morris and Pandey, 2010).

\section{Land use policies}

There are various normative regulations put on housing development in the country pertaining to built-up space, plot sizes, parking spaces, etc. which cause unnecessary waste of land in many locations. These norms are not designed on practical basis and hence, they do not cater to location specific needs. See for instance Bertaud (1996) for detailed analysis. Some of the regulations that are placed on the housing construction in Ahmedabad are mentioned in Appendix VII.

Such policies may be appropriate for some regions but having a blanket policy for all kinds of housing development may not be the best solution. In the current supply crunch scenario, policies that constrain the effective land use such as maximum of $45 \%$ ground coverage provide for artificial constraining of housing. They also leave vast amounts of improperly used land even in the metros which actually subtract greatly from social and public value.

\section{Land transfer policies}

There are various complications associated with land transfer policies. The various complex transactions that are needed for development of a township are cited in Appendix IX. From the table, it can be inferred that the construction of development site happens only after a number of steps which leads to unnecessary hurdles. The process of conversion of agricultural land into non-agricultural land is one of the more tedious processes. Also the stamp duty and registration process are expensive and lead to increase in housing prices. Moreover they are are source of much discord and protest, since farmers would not be able to convert agricultural 
land to other uses, while the aggregator can resulting in vast rents being accumulated by the builders and fixers, and paid to officials in decision making. The various permissions from the Urban Development Department and the Revenue Department make the whole process slow and corruption prone. This whole maze of regulations and permissions lead to constraining of real estate supply. See Morris, Sebastian and Ajay Pandey (2007).

Hence it is important to remove non-agricultural use clearances, streamline the process for land transfer and have a single umbrella body which is responsible for attending all such issues related to land transfer rights, including the institution of proper titles to land. With the current norms and maze of regulations, it is nearly impossible to start a new township or society development without a gestation period of 2 years.

\section{Non-Usage of Govt. Land}

A significant portion of the land occupied by the various government bodies is being wasted. According to initial estimates by the Department of Public Enterprises (Ministry of Finance, 2015b). 2.35 Lakh acres of surplus land lies with public sector undertakings (PSUs) which is completely non-productive currently. Similarly, Railways have 0.38 lakh acres of vacant land. Majority of the government surplus land that is wasted can be utilized for providing housing facilities. This is a measure that can be taken immediately for increasing the land supply. Application of GIS to accurately map existing Government land is an attractive option. Andhra Pradesh is actively pursuing the implementation of a GIS policy in the state (Govt. of AP, 2016).

Under the Cantonments Act, 2006 (earlier Cantonments Act 1924), the Government of India through the Ministry of Defence notifies vast areas as Cantonments. As of 2015, 62 locations occupying 1,86,730 acres have been notified as Cantonments (Ministry of Defence, 2015b). The remaining 15,96,000 acres of military-occupied land lie outside these notified areas. Such colonial-era military stations house 20,91,734 people (including defence personnel and civilians) while occupying approximately 17,82,000 acres of prized lands across 19 Indian states in cities such as Ahmedabad, Bangalore, Delhi, Jabalpur, Kanpur, Meerut, Pune, Secunderabad, Trichy etc. $80 \%$ of this area is concentrated in five populous states of Rajasthan, Madhya Pradesh, Maharashtra, Uttar Pradesh \& Punjab. Based on relative population density alone, these Cantonments can be termed as surplus land lying with the State. Also due to multiplicity of laws such as the Defence Act 1903, there is unreasonable delay in transfer and mutation of properties in these areas due to corruption, restrictions on conversion into freehold land and on new constructions of buildings etc. Technically, however, it is difficult to conclusively state that there is unused surplus land because land is acquired for defence purposes only after its proposed military use is specified and accepted by the government. The use of these defence lands though is vastly suboptimal. The cantonments typically occupy the central areas of cities and their built up densities can be lower than that of rural places. Some like Dehradun have nearly $80 \%$ of their central areas being occupied by a few government organisations, leaving the rest of the population to live in perpetual congestion.

There is a growing need for release of land that is in the possession of government and used very wastefully, especially when these are located in prime areas of central places, because of which there is both the opportunity loss of not using these lands, and the very high costs of urban access imposed on the population that have to move around and through these lands. The locational value weighted quantum of such land in the possession of government could in 
many cities - Kanpur, Pune, Dehradun, railway towns rival or even exceed the land currently in use by citizens.

\section{Non recognition of slums dwellers' rights}

According to the 12th Five Year Plan report (Planning Commission, 2013), 3 million hectares of land have been declared as surplus of which $30 \%$ is caught up in litigations. This is compounded by other clandestine land transfers leading to illegal possession of pieces of land. In some cases, the plots allotted to various beneficiaries under the government policies do not have clear title. Since the cost of housing for even the lower middle classes is very high in areas with reasonable locational value (necessary for accessing the job markets), when slum clearance schemes provide for sites far away from the central places (with little or no locational value), and are not therefore meaningful options for the poor, who then have to live in new "illegal" spaces in urban places. An additional aspect is that the poor get pushed to the unregulated niches (ex-villages within cities). All these create a very large slum and chawl population in most large cities. As evidenced in the affordable housing policy in Brazil (Refer section on Sao Paulo) provision of some kind of legal tenure to squatters is instrumental in controlling urban squalor.

The landless and poor choose to occupy these pieces of disputed lands because they are less expensive than legal and overly regulated housing. With little or no reform of the regulation, there soon emerges an entire market in "illegal" development with its own developers who cater to the needs of those who can't afford housing in the formal sector and choose to stay in such "illegal" sites.

Now, as the disputed land provides no property rights to its occupants, or their land use prohibits them from use for housing, the residents there typically cannot ask for basic municipal facilities such as water and sewerage services, sanitary services, electricity services ${ }^{7}$. This is compounded by the disincentive that occupants have against investments, which could have led to improvement in living conditions as they do not have property rights and are not sure of their tenure. These factors lead to people living in awful conditions in these slums. The functionality of these illegal habitats to the urban places is without doubt. These "illegal" habitats (which are home to as much as $30-50 \%$ of the population) and allow its residents to live and participate in the economic activities; and without their work and services cities could hardly have grown.

Improving the quality of existing slums by provision of basic municipal facilities for the slum dwellers, while limiting the negative externalities of slums on other public services like transportation, road access etc is one of the important ways forward. Affordability for these services could be better than is generally assumed. According to the World Bank Report "Global Partnership on Output-Based Aid (GPOBA) lessons learned", the payments made to middlemen in order to access basic municipal services are greater than that would have been paid if supplied legally to the municipal bodies. No doubt improving the condition of the slums will lead to an incentive for the current slum dweller to increase his tenure in the slum, but this stock of improved slums can be utilized as a launching pad for getting into the formal housing sector. So essentially, we can improve the living conditions of the existing slums, leading to provision of some affordable housing which is suited for quality human inhabitation. See

\footnotetext{
${ }^{7}$ About 15 years the restraint on electricity companies barring them from supplying to such illegal "habitats" have had salutary effect on the quality of life therein and has also allowed electricity companies to expand their network and collect dues from users better.
} 
Clarke et al (2010). Sewerage, sanitation and water supply, since their unit social value increases dramatically with $100 \%$ coverage even from high $80 \%$ (due to the reduction in diseases and overall improvement in the cleanliness and hygiene of public places) are justifiably covered by subsidies as well. Today access costs for the poor are prohibitively high for sewerage and water supply since a formal residence is a necessary condition for such access, not to speak of the very high connection charges, even when use charges are low. ${ }^{8}$

There is an immediate need to resolve these ownership issues by the local judicial bodies in order to have definite property rights and clear land titles. Only when there are clear land titles, a private party would choose to enter and develop the land for commercial purposes. Until then, it is the best option for the parties involved in the dispute over the disputed land to let the slums continue in the area and to collect rents on a regular basis.

Another potential solution could be provision of property rights to these existing "illegal" housing facilities. This legalization (in part) will lead to an immediate surge in prices of this land. As many of the existing slums are situated in prime locations, there will be a very high demand from the formal sector to buy this piece of land at high prices providing enough incentive for the slum dwellers to sell this piece of land. This will lead to a major increase in supply of housing in important city locations easing the problem of long commute times from work to home, horizontal expansion of cities and decreasing built up property prices in prime locations. When such measures are linked to TDRs and to the development of poor housing elsewhere with good but not prime locational value, and with investments in transportation for the ex-slum dwellers to access the central place, considerable enhancement of social and public value is possible.

\section{FRAMEWORK FOR POLICIES ON AFFORDABLE HOUSING}

A policy on affordable housing should aim at two things:

Improving reach of formal market. This can be done through a coordinated approach that involves

Increasing land supply

- Using the vast amounts of land with the government especially in central places more efficiently with affordable housing besides public infrastructure having a larger claim on the same.

- Resolving land title issues by adopting a Torrens System and allowing squatters rights to some part of the land which are convertible to either actual occupancy rights or rights that are transferable to more appropriate locations for affordable housing.

- Increasing FAR/FSI which would have the most impact on value creating affordable housing. The fear of windfall gains to private owners of land suitably located to have higher FSI can be addressed through bid based FSI and / or rights transfer.

- Modify building bye-laws/ sanctions that are archaic in nature and make them more functional and efficient

Removing procedural bottlenecks for construction: These can be carried out by:

\footnotetext{
${ }^{8}$ That subsidies are perverse for the reason that connection fees are generally high while use charges are low in a number of sectors -water, sanitation, electricity, irrigation water have been brought out in Morris, Sebastian (2001).
} 
- Issuing tenure rights (sometimes transferable) to squatters, so that investments to improve the quality of life can take place in these properties.

- Directly subsidizing those who cannot afford a housing in even the most efficient markets

- Non taxing non-poor and non-rich segments and reducing house taxes across the board for all income groups: High end properties could be taxed to cross subsidise public housing and affordable housing.

Prudent Government involvement especially involving recognising and addressing the specific market failures in land, the need to coordinate urban and transport planning with house building so that the locational value for all projects improve greatly by reducing the travel times and costs in commuting; would have to be part of the overarching framework to make housing for all possible.

THE RAJIV AWAS YOJANA PROJECT (RAY) (MoHUPA, 2012a, 2012b, 2012c)

The RAY programme aims at creating a slum free India. It was launched in 2011 in two phases. The "preparatory phase" ended in 2013. The "implementation phase" was sanctioned for action from 2013 to 2022. The two major objectives of RAY can be summed up as follows:

- Legal recognition of slums and bringing them into the formal system

- Redress the failures of the formal system

The RAY comprises of a series of guidelines that govern the many aspects of the program, right from the policy measures to be taken to the way in which these measures must be implemented. For our study, we shall focus only on the policy measures proposed by this scheme. We do not carry out a microlevel analysis of implementation of the said policies. The efficacy and potent of the said measures will be analysed vis-a vis the policy framework described in the previous section. RAY is among the most comprehensive projects thus far from the government. Policy reforms to tackle the problems of affordable housing are an integral part of the scheme. They build on the policy reforms on the urban poverty alleviation reforms of the JNNURM scheme. This section will critique the policy measures under RAY in the light of the framework developed in the previous section.

The key features of the programme are listed below, which are examined further.

\section{$\underline{\text { Slum Intervention Strategies }}$}

- Provision of dwelling units in all tenable slums

- Wherever in-situ development is not possible, the slum dwellers must be rehabilitated elsewhere (designated untenable)

- Homeless and pavement dwellers to be included in adjoining slums or to be relocated.

- The slum intervention strategies would be of three types:

a) Upgradation: Includes upgradation of kuchha to pucca houses, incremental addition of rooms and provision of basic services

b) In-situ redevelopment

c) Resettlement: Relocation to nearby zones slums that cannot be rehabilitated.

\section{$\underline{\text { Slum Prevention Strategies }}$}

- Assessment of supply side constraints: The programme to address time consuming land approvals processes, constraining building rules etc. 
- Assessment of constraints to rental housing to free up the rental markets.

- Review of demand side constraints: This would pertain to supply of credit and the penetration of micro-finance institutions

\section{Affordable housing in Partnership Scheme}

- Subsidization up to 75,000 per DU of size up to $40 \mathrm{~m}^{2}$.

- Minimum of 250 DUs with a mix of EWS/ LIG/ Higher categories and commercial

- $60 \%$ of FSI to be used for DUs of carpet area not more than $60 \mathrm{~m}^{2}$

Assignment of lease rights

- Assignment of lease rights to a dwelling unit for slum dwellers who have been residents of the slum for more than 5 years.

- These rights will be mortgage able, renewable, and inheritable.

- The lease rights shall be in form of a title deed in the name of the female of the household.

- The slum dwellers who are not eligible for leasehold rights shall be covered with rental housing in the form of dormitories and night shelters

\section{Cross subsidization and incentives to developers}

$15 \%$ of FSI or $35 \%$ of dwelling units are to be reserved for EWS/ LIG in future housing projects. In return, the developers will be granted relaxations in terms of FAR restrictions, building bye-laws and land use concessions.

\section{Earmarking of $25 \%$ of municipal budget}

Basic delivery of civil and social services are to be provided for urban poor including slum dwellers.

\section{$\underline{\text { State policy reforms }}$}

- Constitution of a land bank by State/ UTs to be allocated for affordable housing

- Streamlining the process of giving clearances and approval of affordable housing projects to constrain them to a certain timeframe.

- Nominal stamp duty for EWS/ LIG housing

Master Plan amendments

Recognize slums and poor neighbourhoods in non-conforming but non-objectionable land use status. Hazardous areas such as low lands, lakes, areas close to polluting industries are not covered. Such recognized tenable lands would be designated as residential or mixed use.

\section{Simplification of sanctioning process and building bye-laws}

- Single window approval for building sanctions and bye-laws

- Online process to be introduced

\section{$\underline{\text { Improving access to credit }}$}

- Rajiv Rinn Yojana/ Interest Subsidy Scheme for Housing the Urban Poor:

a) Interest subsidy of 5\% on long term loans (15-20 yrs.) 
b) Ceiling of ₹ 5 lakh for EWS and ₹ 8 lakh Lakh for LIG

Credit Risk Guarantee Fund (CRGF): Coverage of up to $85 \%$ of loans to EWS/ LIG.

\section{EVALUATION OF THE RAY SCHEME}

The "framework for policies on affordable housing" is used to evaluate the RAY scheme.

Usage of Government land :The proposal to construct a land bank under the "State policy reforms" of RAY can definitely free up some Government land for use in affordable housing projects.

Easing restrictive Govt. policies/ Removal of procedural bottlenecks: The slum intervention policy measure attacks the procedural bottlenecks part of the affordable housing policy. It also seeks to tackle the demand side problem. However, the demand side problem is not as significant. In urban India, it is more a question on affordability than access to credit.

The "state policy reforms" of RAY also seek to remove procedural bottlenecks for only affordable housing projects. However, streamlining the process for only affordable housing is unlikely to impact the land supply in any significant way. Procedural bottlenecks must be removed on a systemic basis.

The credit policy under the RAY scheme tackles the issue from the demand side, which is not as significant a problem in India. Hence, this is not the most important issue.

Taxation of affordable housing projects: As per the KPMG report (KPMG, 2014), "Decoding Housing For All 2022", a significant percentage of the cost ( 35\%) is due to taxes. The levy of nominal stamp duty can hence have significant impact on affordable housing costs.

Increasing FAR: RAY tackles this problem to some extent when it proposes easier FAR norms for developers in its cross-subsidization scheme. While such relaxations do tackle the problem of low FARs and restrictions on density, it is not the most efficient solution. The price reduction due to FAR and density relaxations is offset by the cross-subsidization. Moreover, the FAR relaxations will be effective when it is across the board for all types of housing projects. While narrow relaxations do tackle the issue to some extent, significant effects can be felt only after systemic implementation of this relax.

Subsidization of housing for the poor: "Affordable Housing through partnership" measure will allow for efficient development of housing societies by subsidizing those who cannot avail housing through the formal market.

Cost outlay for Government; The "affordable housing in partnership" scheme bypasses the massive expenditure of a direct housing policy (Appendix II).

Assignment of lease rights: RAY actively tackles the problem of tenure rights. Assignment of lease rights will tackle critical problem of dwellers not investing in their living conditions. This will also reduce frictions in transactions of their properties and increase liquidity in the housing market.

Addressing tenure rights: The "Master Plan amendments' of RAY also addresses the issue of tenure rights for slum by recognising tenable land titles. 


\section{“HOUSING FOR ALL 2022”}

The policies which have been envisaged by the governments over the years have been some modification of "Housing For All 2022" (HFA) policy (MoHUPA, 2015b) that has currently been introduced. The HFA policy envisages providing, according to the President's Speech, "every family with a pucca house with water connection, toilet facilities, $24 \times 7$ electricity supply and access".

The housing shortage in the country is divided into 4 parts as per the MHUPA report on HFA 2022:

i) Slum dwellers

ii) Urban poor living in non-slum areas

iii) Prospective migrants

iv) Homeless and destitute

The government policy for slum dweller and urban poor living in non-slum areas would have to be considered.

The policy for slum dwellers is itself divided into 3 parts:

i) Slums on public land

ii) Slums on private land

iii) Unauthorized colonies as slums

The major points under the strategy for slums on public land are:

- In-situ redevelopment or upgradation of the public land on the basis of private partnership by using land as a resource

- Provision of higher FSI to such lands

- Private party to exploit part of the land with increased FSI for commercial purpose

- Private party to build part of the land for eligible slum dwellers at free of cost (cross subsidization)

- GOI and State Governments to share the burden of the viability gap, if any

The major points under the strategy for slums on private land are:

- In-situ redevelopment or upgradation of the slums by the freeing up part of the land for commercial use with higher FSI to the owner and the shifting the slum to a lesser area with higher FSI

- Government to provide technical specification and area norms

The major point under the strategy for slums living in untenable land such as river bed, forests, drain, high tension line, etc. is to shift such slums to other tenable areas. The major points under the strategy for slums on unauthorized colonies are:

- Regularization of these colonies

- Provision and improvement of basic municipal services such as roads, sanitation, sewerage, water services and electricity in these areas

- Improvement of general infrastructure

The policy also aims at resolving some of the supply side issues with the following interventions: 
- Government bodies which already have slums on their lands, such as Railways-1198 acres of slum, Ministry of Defence- 2876 acres of slum, Department of Public Enterprise- 5800 acres of slums etc., would free up some part of their land

- Provision of extra FSI for Affordable Housing

- Easier Window Clearance for building permission and deemed NA (Non-Agricultural Use) permission

\section{EVALUATION OF HOUSING FOR ALL BY 2022 SCHEME}

Analysing this policy against the framework for affordable housing policies

Usage of Government Land: This policy tries to leverage the government occupied land in a small way by utilizing the currently government land occupied by squatters. The policy in a way tries to free up that land by separating it into 2 parts- one for affordable housing and the other for commercial purpose. However, it would have been even better if there would have been a policy clause where the government bodies which are sitting on vast pieces of unoccupied and unused land were made to give up their lands or asked why the lands currently vacant or under suboptimal use should not be taken away for public use / housing development. There is likely to be considerable resistance from the public bodies against any such move. Hence, the proposed policy of usage of occupied government land by slum dwellers in itself can be seen as a first step to a more radical but necessary measure of making the public bodies relinquish the unoccupied piece of land, or to put them to optimal use. Lands available with the government could have been traded for other lands or directly used in development of affordable housing projects instead of letting it out into the market. This way while the supply of dwelling units in market will increase, it will also then be in the affordable housing segment.

Land under litigation, disputes and property right issues: The HFA-2022 policy tries to leverage the private land under dispute by providing higher FSI to the private party and simultaneously providing for Affordable Housing in the same land. Also, the HFA 2022 aims at regularizing the unauthorized colonies, provision and improvement of basic municipal services such as roads, sanitation, sewerage, water services and electricity in these areas and a general improvement in the infrastructure. However, the policy is silent on many aspects of property rights/tenure rights of the people currently living in slums. The policy does not try to resolve the property rights problems that are one of the primary reasons for poor conditions of the existing slums.

Restrictive Land Transfer Policies: The HFA-2022 policy tries to address the problem of convoluted land transfer policies and difficult agricultural to non-agricultural land policies. The policy accounts for easier clearance window for various permissions and deemed NA permission. This is a significant step in the direction of removing the bottleneck between land occupation and land development. However overall abolition of NA Clearance would have removed one major perversity in urban land markets that jacks up the cost of land for housing and urban use, and prevents wider participation in the land aggregation and development parts of the value chain.

FAR Norms: The policy tries to provide for a higher FAR in the public and private lands where there will be a provision of affordable housing construction. This will serve as an incentive for the private player to develop the land for commercial purposes and at the same time develop housing solutions for the slum dwellers/poor which are affordable, regulated and have proper municipal facilities. However, the policy does not address the problem a higher FAR in 
general (i.e. for properties other than affordable houses). This essentially means that the policy does not resolve the land supply constraint due to lower FAR in anyway. Hence, the policy will have low impact in reducing the property prices in any significant manner.

Land Use Policies: The policy is silent on the blanket approach by the government/local bodies in deciding the land use policies.

\section{SAO PAULO AND AFFORDABLE HOUSING PROGRAMMES}

According to the United Nations Human Settlements Programme (UN-HABITAT), the global urban population is set to grow at an average rate of 1.78 per cent per year between 2005 and 2030. This is double the expected rate of growth of the total population during the same period. UN-HABITAT also predicts that the number of people living in urban squalor (i.e. slums and shantytowns) could total 3 billion in $2050^{18}$. Importantly, the United Nations Population Fund (UNFPA) State of World Population 2007 report $^{19}$ foretells that even as cities contain concentrations of poverty, they shall ultimately also represent the best hope for combating it. This rings true when we take the case of Sao Paulo.

With a resident population of about 10 million, the Sao Paulo city region is also South America's most populated urban cluster. In the mid-2000s, it was estimated that urban squalor took up $70 \%$ of Sao Paulo's area housing two million people.

Sao Paulo's urban squalor was of two types:

Slums : These were houses on the periphery of Sao Paulo's city limits. These were essentially large houses occupied by several families separated by ephemeral internal divisions. These had existed around Sao Paulo since the start of Sao Paulo's modernization, i.e. early $20^{\text {th }}$ century. By 1990's 20\% of Sao Paulo's urban poor lived in slums within the city limits. These are locally known as corticos.

Shantytowns: These were self-built huts built with inadequate materials within city limits mostly on the municipal authority's empty areas, and much less frequently, on private properties. They arose together in great numbers in the second half of the $120^{\text {th }}$ century. These are locally known as favelas. More than $60 \%$ of the population growth in the 1980 s is considered to have been absorbed by the favelas.

Both these illegal kinds of residences were the result of the impossibility of having access to housing through the market since the market had already dedicated itself to focus on the supply of residences for the middle and upper classes of the city. The basic characteristic of the slums and shantytowns were:-

- There was a payment of unauthorized rent even in the absence of a rental contract.

- Living conditions did not follow the legal requirements.

- Living conditions were unhygienic.

The urban problems of Sao Paulo may be listed as follows:

- The rising cost of constructing houses for the upper and middle classes made such construction more profitable. Consequently, the supply of affordable housing for the other income segments was left to the state. However, the construction of state (public) housing 
was too slow to absorb the growing demand. As a result, the people at the margins were pushed towards squalor-type arrangements.

- Historically, the FAR had been low in Sao Paulo, generally in the range of 1-2. Such a low FAR contributed to the restricted supply of housing and development of other infrastructure in the centre of the city. This also resulted in development of peripheral and poor housing.

\section{Sao Paulo's innovations in urban housing problems $^{20}$}

Over a period of more than 50 years, the municipal, state and federal authorities exhausted several approaches in order to find that one correct solution. Several phases could be seen in the initiatives of the government before affordable housing could become a reality in Sao Paulo:

\section{Phase 1: Forcible Eviction and Federal Domination (1960s - 1980s)}

- This was the dominant mechanism of eliminating urban squalor. Force and punishments were used to evict the urban poor and regain land.

- However, the eviction of favelas from the city limits drove the poorest to the most peripheral and hazardous areas [floodplains, hill slopes, forest lands etc.].

- This phase also saw the emergence of federal funding through Brazil's National Bank $(\mathrm{BNH})$ and cooperative banks such as Incoop.

\section{Phase 2: Implementation of the "Singapore Model (Cingapura Project)"}

In Singapore, during the 1960s, about 1.3 million of the total 1.9 million population lived in urban squalor. In 1960, the Housing and Development Board (HDB) was set up to solving the nation's housing crisis, and important goal of the HDB was also to push home ownership in order to foster a stronger sense of Singapore as the home country. Gradually, rented apartments were built for the poorest who could not afford to buy out the houses in instalments. As a result, by the mid-1980s, through public housing policies, Singapore was more or less slum and squatter free.

\section{Sao Paulo's modification to the model:}

The administration of Mayor Luiza Erundina (1989-1992) tried to unsuccessfully speed up public house building by creating its own "Singapore Model". Self-help housing initiatives, known as 'mutiroes' were emphasized. Community groups were directly funded. Such groups engaged local families to build new houses or to renovate existing houses. Core to the approach were the following features:

- Slums received priority and most of the upgradation and new construction took place within or very close to existing slums and shanty towns. Ownership was bestowed on the COHAB (a public - private special venture), which collected rents (R \$57.00 per month)

- A social worker oversaw the transfer of families from favela to temporary settlements to new housing unit

- Landscaping and leisure areas were included in the layout of development plans. 


\section{Results of the policy}

- While there was general encouragement for the initiative, a range of problems resulted in only 14,000 units being constructed as opposed to the 100,000 originally planned possibly also because only a fraction of the proposed funding was made available

- The unit cost escalated sharply and although rents were set modestly they proved beyond the means of many who fell behind with their payments

- Once buildings were occupied, residents began to identify serious quality of life issues. Living space widely seen as being inadequate. There was much criticism of the lack of provision to conduct home based and small businesses in the project

This decade is referred to as the 'lost decade' because the state housing construction rate was so slow that favelas broke out of its traditional urban peripheral confines and spread all over the city to become the new archetype of slum. They did so by occupying just about every empty or unprotected urban lot, as also where construction was difficult, or had little value to the formal market.

The resulting chaos finally led the Federal Government to enact in 2001, of a "City Statute" requiring cities to bring forth and develop master plans. It also provided a set of tools that municipalities could use to control land transfer, and to work out legal tenure for tenants - a process Sao Paulo formally integrated into its own master plan a year later.

Phase3: Slum Upgradation and Peoples Involvement (2000 To 2013)

Mayor Marta Suplicy, who was a socialist was elected in 2000. She brought in a new approach and strategy for housing.

- The new strategy was designed to obtain "maximum impact for minimum cost". The concept of the mutirao [self-help scheme] was revived. Families were assisted in selfconstruction or upgrading of their own homes.

- Each renovation cost around US $\$ 3,000$ per family - a significantly smaller sum than would be required to build an entirely new home. The house unit cost of self-help schemes was between $\$ 11,000$ and $\$ 15,000$ compared to over $\$ 20,000$ for housing units in the Cingapura Project. Such home improvements could radically improve the health of a family and ultimately foster a cycle of local development.

- Zones of special interest were created for disorganized slums, formally recognizing their existence and qualifying them for social services. Another tool authorized joint citizengovernment management councils both in new and more settled areas.

- The new administration also promised to spend $\$ 3$ billion on housing during its term in office, which included completing the 1000 unfinished Cingapura housing units.

- The Municipal Housing Council, created by the city in 2002, to act as a watchdog, and which had a direct role in deciding how housing fund moneys could be spent, was activated. Its members came from government agencies, unions, from socially oriented non-government organizations, and academics. Members of the Council are elected in polls open to all São Paulo citizens. The Council is widely perceived to help guarantee the continuation of policies.

The Santo Andre Success ${ }^{21}$

This scheme was particularly well executed in the Santo Andre slum of Sao Paulo. The project officially titled "Strategies for Planning, Financing, and Sustainable Implementation of 
Housing and Urban Development Policy" was developed by SEHAB (city municipality) and the Cities Alliance with support from the World Bank during the second phase of the technical cooperation effort. Begun in December 2005, the project achieved the following:

- "Well targeted government interventions in the urban sector fostered to enable people to create more urban livelihoods.

- The active participation of the urban poor in decision-making promoted effective formulation and implementation of local action plans.

- The participatory budgeting process, an innovative approach to urban governance and decision-making, provided a real voice for the urban poor in both the allocation and use of municipal and other resources.

- The Municipality of Santo André has shown that while effective leadership needs to be ensured by the local administration it, in turn, needs to devolve decision-making and implementation powers to the community." (World Bank, 2015)

This demonstrates that Inter-agency "collaboration and effective channels of communication between various actors and stakeholders is critical to successful slum improvement and reduction of poverty and social exclusion. Principles of equity, civic engagement" and tenure security are key to success (World Bank, 2015).

\section{Lessons from Sao Paulo}

The lessons that Sao Paulo learnt are listed as follows:-

\section{Coordinated public private engagement}

Solving different housing and environmental problems requires a commitment by all of the actors involved. Involvement of local communities, and coordinated problem solving approach has far better success than top down bureaucratically driven programmes. Community leaders have active roles as a mediators and translators between the local residents and the government. Social work with the communities is necessary even after construction for the realisation of satisfactory transition.

\section{Social inclusiveness}

A well-executed affordable housing program achieves social inclusiveness. By upgrading slums and regularising more than 60,000 dwellings in favelas and informal subdivisions, the social rental programmes and slum tenement improvement programmes also upgrades the central areas of the city with social inclusiveness. Providing an avenue of income generation consistent is one of the elements of success.

\section{How to achieve legal tenure?}

Much progress can be made by resorting to changes in law. Providing for a legal tenure specifically requires three elements to be workable.

- First, is the location right for human settlement? (I.e.it should not be for example, pose water pollution risk because its location is too steep or on a flood plain, or too far into the urban periphery). Extensive informal occupation of areas with very high risks of accidents and pollution, for example, must be prevented.

- Second, is the settlement legally registered? Is it part of the database of city properties? 
- Third, do its residents have legal title to the land? And if not, how can they be assured of secured tenure?

There are clear rewards of providing legal tenure. Families that have their land title confirmed, or or have been granted a certificate recognizing their occupancy rights, can be asked to pay some taxes. Similarly, building rules can be set (and enforced) to prevent building collapse when the occupants have rights to the land. Regular streets, schools and clinics can be developed, attracting further investments in improvement by the dwellers. Also it's easier to reduce litter by organizing residents to bring their own household waste to collection points for city pick-up. But going the whole way continues to be difficult. Even in Sao Paulo, while the city government works hard to give land tenure, property rights are only conceded by law once this possession is recorded in a register office. The complete process has occurred only with a few properties. In most cases dwellers received a document without clear legal value. 


\section{Appendix I:}

State of Housing in India Compendium, (MoHUPA 2013 in millions of units)

Kutcha Households

Obsolescent Households

Congested Households

Homeless Households

Total Housing Shortage

18.78

EWS Housing Shortage

10.55

LIG H Shortage

MIG+HIG H Shortage

0.82

Total Housing Shortage

18.78

Source: State of Housing in India Compendium, (MoHUPA -2015c)

Appendix II:

Average Property Prices in Ahmedabad c. 2015 ( $/$ / Sq Ft

\begin{tabular}{|c|c|c|c|}
\hline Locality & Minimum & Maximum & Average \\
\hline $100 \mathrm{ft}$ Road & 5,139 & 6,163 & 5,651 \\
\hline 132 Ft Ring Rd & 4,234 & 5,294 & 4,764 \\
\hline Ajaynagar & 1,833 & 1,833 & 1,833 \\
\hline Akhbarnagar & 4,000 & 4,000 & 4,000 \\
\hline Alkapuri & 2,897 & 4,105 & 3,501 \\
\hline Amar Park & 556 & 556 & 556 \\
\hline Ambawadi & 4,429 & 6,613 & 5,521 \\
\hline Ambli & 4,375 & 4,750 & 4,562 \\
\hline Amraiwadi & 2,685 & 5,571 & 4,128 \\
\hline Anand & 1,071 & 1,357 & 1,214 \\
\hline Anand Nagar & 4,085 & 7,500 & 5,792 \\
\hline Anand Park & 7,143 & 7,143 & 7,143 \\
\hline Baroda & 2,364 & 2,364 & 2,364 \\
\hline Bhimji Pur & 3,478 & 3,478 & 3,478 \\
\hline Bhopal Sardar Patel & 3,125 & 4,375 & 3,750 \\
\hline Bhor & 2,500 & 2,500 & 2,500 \\
\hline Bhujangadev & 3,241 & 3,241 & 3,241 \\
\hline Bodakdev & 4,698 & 6,114 & 5,406 \\
\hline Bopal & 2,885 & 3,502 & 3,193 \\
\hline C G Road & 3,841 & 4,788 & 4,314 \\
\hline Cellar Rest & 2,700 & 2,700 & 2,700 \\
\hline Chand Khera & 2,222 & 2,222 & 2,222 \\
\hline Chandkheda & 2,421 & 3,704 & 3,062 \\
\hline Chandlodia & 2,735 & 2,889 & 2,812 \\
\hline Changodar & 1,578 & 1,920 & 1,749 \\
\hline Chenpur & 3,390 & 5,423 & 4,406 \\
\hline CTM & 2,129 & 2,129 & 2,129 \\
\hline Dakshini Society & 35,714 & 35,714 & 35,714 \\
\hline Dholera & 371 & 371 & 371 \\
\hline Drive In Rd & 4,235 & 5,329 & 4,782 \\
\hline Dudheswar & 4,085 & 4,085 & 4,085 \\
\hline
\end{tabular}




\begin{tabular}{|c|c|c|c|}
\hline Ellis Bridge & 3,901 & 3,901 & 3,901 \\
\hline Gandhi Park & 2,407 & 2,407 & 2,407 \\
\hline Gandhinagar & 2,231 & 3,273 & 2,752 \\
\hline Ghatlodia & 3,292 & 3,605 & 3,448 \\
\hline Gota & 2,667 & 3,019 & 2,843 \\
\hline Gulbai Tekra & 5,646 & 7,062 & 6,354 \\
\hline Gurukul & 3,822 & 4,800 & 4,311 \\
\hline Haripura & 2,917 & 2,917 & 2,917 \\
\hline Hirapur & 1,624 & 1,624 & 1,624 \\
\hline Indrajit & 100 & 100 & 100 \\
\hline Isanpur & 2,602 & 3,012 & 2,807 \\
\hline Jagatpur & 3,515 & 4,032 & 3,773 \\
\hline Jamalpur & 2,468 & 2,843 & 2,655 \\
\hline Jivraj Park & 3,148 & 3,833 & 3,490 \\
\hline Jodhpur gam & 5,508 & 8,116 & 6,812 \\
\hline Jodhpur Village & 3,121 & 4,248 & 3,684 \\
\hline Juhapura & 1,420 & 2,991 & 2,205 \\
\hline Kakaria & 4,000 & 4,000 & 4,000 \\
\hline Kalavad Road & 1,417 & 1,417 & 1,417 \\
\hline Kankaria & 4,000 & 4,724 & 4,362 \\
\hline Khodiyar Nagar & 3,286 & 3,286 & 3,286 \\
\hline Khokhra Mehmadabad & 2,912 & 2,912 & 2,912 \\
\hline Koba & 2,517 & 2,913 & 2,715 \\
\hline Koteshwar & 4,699 & 4,699 & 4,699 \\
\hline Krishna Nagar & 5,142 & 8,600 & 6,871 \\
\hline Lambha & 1,667 & 1,741 & 1,704 \\
\hline Madalpur & 60,000 & 60,000 & 60,000 \\
\hline Madhuban & 33,000 & 33,000 & 33,000 \\
\hline Maharaj Gagdish & 5,168 & 5,168 & 5,168 \\
\hline Makarba & 3,525 & 3,891 & 3,708 \\
\hline Motera & 2,750 & 5,000 & 3,875 \\
\hline Nana Chiloda & 1,722 & 1,722 & 1,722 \\
\hline Nar Narayan Nagar & 2,735 & 2,735 & 2,735 \\
\hline Naranpura & 3,316 & 4,758 & 4,037 \\
\hline Narayan Nagar & 5,185 & 5,185 & 5,185 \\
\hline Naroda & 1,722 & 1,963 & 1,842 \\
\hline Narol & 1,778 & 1,929 & 1,853 \\
\hline Navrangpura & 3,889 & 5,762 & 4,825 \\
\hline New C G Road & 2,286 & 2,764 & 2,525 \\
\hline New Ranip & 2,551 & 2,771 & 2,661 \\
\hline New Vadaj & 2,979 & 3,969 & 3,474 \\
\hline Nikol & 1,909 & 2,296 & 2,102 \\
\hline Nirnay Nagar & 3,210 & 3,641 & 3,425 \\
\hline Odhav & 1,778 & 1,916 & 1,847 \\
\hline Old Vadaj & 2,322 & 2,322 & 2,322 \\
\hline Paldi & 4,278 & 5,179 & 4,728 \\
\hline Panchvati & 4,854 & 4,854 & 4,854 \\
\hline Pethapur & 1,606 & 1,682 & 1,644 \\
\hline Prahlad Nagar & 4,172 & 5,719 & 4,945 \\
\hline
\end{tabular}




\begin{tabular}{|l|r|r|r|}
\hline Prakash Nagar & 2,941 & 2,941 & 2,941 \\
\hline Raghuvir & 4,365 & 4,365 & 4,365 \\
\hline Railway Colony & 3,000 & 3,000 & 3,000 \\
\hline Rajendra Park & 4,000 & 4,000 & 4,000 \\
\hline Rajnagar & 4,021 & 4,540 & 4,280 \\
\hline Shahpur & 1,853 & 2,000 & 1,926 \\
\hline Shahvadi & 2,444 & 2,444 & 2,444 \\
\hline Shanti Nagar & 4,941 & 8,757 & 6,849 \\
\hline Sharada Nagar & 4,950 & 4,950 & 4,950 \\
\hline Shastri Nagar & 4,000 & 9,997 & 6,998 \\
\hline South Bopal & 3,325 & 3,648 & 3,486 \\
\hline Subhash Bridge & 3,535 & 4,007 & 3,771 \\
\hline Sughad & 2,477 & 2,540 & 2,508 \\
\hline Talau & 1,992 & 1,992 & 1,992 \\
\hline Tapovan & 2,800 & 2,800 & 2,800 \\
\hline Thakkarbapu Nagar & 1,792 & 1,792 & 1,792 \\
\hline Thaltej & 4,167 & 5,031 & 4,599 \\
\hline Thergaon & 4,375 & 5,212 & 4,793 \\
\hline Tragad & 2,750 & 2,750 & 2,750 \\
\hline Usman Pura & 1,902 & 22,306 & 12,104 \\
\hline Vadaj & 2,525 & 4,000 & 3,262 \\
\hline Vadsar & 1,552 & 1,933 & 1,742 \\
\hline Vaishno Devi & 2,750 & 3,407 & 3,078 \\
\hline Vallabh Nagar & 4,082 & 5,677 & 4,879 \\
\hline Overall Ahmedabad Average & & & 4692 \\
\hline Source: Property Rates and Trends in Ahmedabad, Sulekha & & \\
\hline & & & 23 \\
\hline
\end{tabular}

\section{Appendix III:}

Computation of Monthly Income Requirements for Affording a Small Tenement of 250 sq ft. Area

Rate per sq ft (from Appendix II)

$\mathrm{Sq}$ Ft required per unit

Price per Unit (A) $4692 \quad ₹$

250* $\quad \mathrm{Sq} \mathrm{Ft}$

Rate of Interest ( $r$ )

Maturity (n)

11.73 ₹ Lakh

Savings Rate (s)

$10 \% *$
Per annum

Equated Annual Payments $(\mathrm{X})=\mathrm{A} * \mathrm{r} /\left(1-1 /(1+\mathrm{r})^{\mathrm{n}}\right)=1.568$ Lakh $₹$ Equated Monthly Payments $(\mathrm{EMI})=\mathrm{X} / 12=12,852$ ₹

Monthly Income Required $=$ EMI/ s = 40,162 ₹

NB:

- $\quad$ Averaging the data from Task Force Report on Affordable Housing, $2012^{26}$

- $\quad$ Average of SBI - 9.85, HDFC - 9.5\% \& Axis - $11.75 \%$ for $10-15$ years as of 2016

- $\quad$ Average tenure is 10-15 years according to newspaper reports

- $\quad 32 \%$, average of savings rate for the years 2011-14 World Bank

(http://data.worldbank.org/) 


\section{Appendix IV:}

Income Distribution of Households in Ahmedabad

\begin{tabular}{l|c|c|c|}
\hline Class & Annual Income & Households in million & \% of households \\
\hline Low Income & 138,000 & 0.27 & 30.00 \\
\hline Aspirants & 276,000 & 0.42 & 47.00 \\
\hline Middle Class & $1,380,000$ & 0.18 & 20.00 \\
\hline High Income & $2,760,000$ & 0.9 & 3.00 \\
\hline Total & & 1.77 & 100.00
\end{tabular}

Source - World Bank Policy Research Working Paper ${ }^{25}$

\section{Appendix V:}

Cost Outlay of Direct Housing Policies (Table1: Cost outlay for RAY in Ahmedabad)

\begin{tabular}{|r|l|r|}
\hline & Description & Cost per Unit (₹) \\
\hline A & Building Work & \\
\hline 1 & Cost of civil works & 400000 \\
\hline 2 & Cost of electrical works & 20000 \\
\hline 3 & Cost of P\&S works & 20000 \\
\hline 4 & Apportioned cost of lift & 35000 \\
\hline & Total Amount (A) & 475000 \\
\hline & & 5000 \\
\hline & Infrastructural Works & 3500 \\
\hline 1 & Cost of water supply & 25000 \\
\hline 2 & Cost of sewerage & 3000 \\
\hline 3 & Cost of roads & 15000 \\
\hline 4 & Cost of SWM system & 1000 \\
\hline 5 & Cost of streetlights & 52500 \\
\hline 6 & Cost of landscaping & \\
\hline & Total Amount (B) & \\
\hline Source: & EWS unit cost $-6^{\text {th }}$ CSMC Report on Affordable Housing in Partnership (AHP) at \\
\hline Chenpur in Ahmedabad (Gujarat Housing Board) ${ }^{24}$ & \\
\hline
\end{tabular}




\begin{tabular}{|c|c|c|}
\hline & $\begin{array}{c}\text { Appendix V: } \\
\text { Cost Outlay of Direct Housing Pol } \\
\text { (Table 2: Working Out the Cost of Providing }\end{array}$ & \\
\hline & Description & \\
\hline A & Building and Infrastructure Cost & \\
\hline & Housing shortage (2012) (in millions) & 18.78 \\
\hline & Cost of building construction/unit (Rs.) & 475000 \\
\hline & Cost of infrastructure development (₹) & 52500 \\
\hline & Cost of housing direct provision(excluding land costs) (₹) & 9.9 trillion \\
\hline & India's GDP (2012) (₹) & 111.6 trillion \\
\hline & Cost of housing provision/GDP & $9 \%$ \\
\hline B & Land Cost & \\
\hline & Land costs (Rs. per ft.) & 2500 \\
\hline & Minimum dwelling size (sq.ft) & 250 \\
\hline & Housing shortage (2012) (in millions) & 18.78 \\
\hline & Total land cost (₹) & 11.7 trillion \\
\hline & India's GDP (2012) (₹) & 111.6 trillion \\
\hline & Cost of land/GDP & $11 \%$ \\
\hline & Total of providing housing for all / GDP & $19 \%$ \\
\hline
\end{tabular}

\begin{tabular}{|c|c|c|c|c|}
\hline \multicolumn{5}{|c|}{$\begin{array}{c}\text { Appendix V: } \\
\text { Cost Outlay of Direct Housing Policies } \\
\text { (Table 3: Trends in Government Expenditure on Housing) }\end{array}$} \\
\hline & $2010-11$ & 2011-12 & $2012-13$ & 2013-14 \\
\hline Gross Capital Formation $(\%)^{\mathrm{a}}$ & $38 \%$ & $37 \%$ & $32 \%$ & $32 \%$ \\
\hline Gross Fixed Capital Formation $(\%)^{b}$ & $34 \%$ & $31 \%$ & $30 \%$ & $29 \%$ \\
\hline $\operatorname{GDP}(\mathrm{Cr} .)^{\mathrm{c}}$ & 8832000 & 9988000 & 11345000 & 12541000 \\
\hline Government expenditure on housing $(\mathrm{Cr} .)^{\mathrm{d}}$ & 21520 & 22012 & 24986 & 32426 \\
\hline Government spending on housing as \% GDP & $0.24 \%$ & $0.22 \%$ & $0.22 \%$ & $0.26 \%$ \\
\hline
\end{tabular}




\begin{tabular}{|c|c|c|c|c|}
\hline \multicolumn{5}{|c|}{$\begin{array}{c}\text { Appendix VI: } \\
\text { Sensitivity Analysis* of Property Prices to FSI /FAR }\end{array}$} \\
\hline Plot Size (A) & \multicolumn{2}{|r|}{$\mathrm{Sq} \mathrm{ft}$} & \multicolumn{2}{|r|}{6000} \\
\hline Land Cost (B)(Appendix V Table 2) & \multicolumn{2}{|r|}{ ₹/ Sq ft } & \multicolumn{2}{|r|}{2500} \\
\hline Total Land Cost $(\mathrm{C})=(\mathrm{A}) *(\mathrm{~B})$ & \multicolumn{2}{|c|}{$₹$} & \multicolumn{2}{|r|}{$1,50,00,000$} \\
\hline FSI (D) & \multicolumn{2}{|r|}{-} & \multicolumn{2}{|r|}{1} \\
\hline Total Buildable Area $(E)=(A) *(D)$ & \multicolumn{2}{|r|}{$\mathrm{Sq} \mathrm{ft}$} & \multicolumn{2}{|r|}{6000} \\
\hline Size of a Dwelling Unit (F) & \multicolumn{2}{|r|}{$\mathrm{Sq} \mathrm{ft}$} & \multicolumn{2}{|r|}{250} \\
\hline Number of Units $(\mathrm{G})=(\mathrm{E}) /(\mathrm{F})$ & \multicolumn{2}{|r|}{-} & \multicolumn{2}{|r|}{24} \\
\hline Component & \multicolumn{2}{|c|}{ ₹ Per Unit } & \multicolumn{2}{|c|}{$₹$ Per Sq Ft } \\
\hline Land Cost & \multicolumn{2}{|c|}{$6,25,000$} & \multicolumn{2}{|c|}{2500} \\
\hline $\begin{array}{l}\text { Construction Cost (Appendix V, Table } \\
\text { 2) }\end{array}$ & \multicolumn{2}{|c|}{$4,75,000$} & \multicolumn{2}{|c|}{1900} \\
\hline $\begin{array}{l}\text { Infrastructure Cost (Appendix V, Table } \\
\text { 2) }\end{array}$ & \multicolumn{2}{|c|}{52,500} & \multicolumn{2}{|l|}{210} \\
\hline Total Cost & \multicolumn{2}{|c|}{$11,52,500$} & 4610 & \\
\hline Total Cost per & Init & Total C & Sq ft & Percentage Decrease \\
\hline $11,52,500$ & & & & \\
\hline $9,44,167$ & & & & $18 \%$ \\
\hline $8,40,000$ & & & & $27 \%$ \\
\hline $7,77,500$ & & & & $33 \%$ \\
\hline $7,35,833$ & & & & $36 \%$ \\
\hline $6,83,750$ & & & & $41 \%$ \\
\hline $6,52,500$ & & & & $43 \%$ \\
\hline
\end{tabular}

\begin{tabular}{|l|l|c|}
\hline \multicolumn{2}{|c|}{$\begin{array}{c}\text { Appendix VII: } \\
\text { Building By-Laws (Ahmedabad) }\end{array}$} \\
\hline Sr. No. & Particulars & Design as per GDCR \\
\hline 1 & Parking + COP & $35 \%$ \\
\hline 2 & Distance between two building & $15 \mathrm{ft}$. \\
\hline 3 & Staircase & $5 \mathrm{ft}$. \\
\hline 4 & Corridor & $5 \mathrm{ft}$. \\
\hline 5 & Ground coverage & $45 \%$ \\
\hline 6 & Unit size/carpet & 250 \\
\hline 7 & Unit built up & 280 \\
\hline 8 & Structure & G+3 \\
\hline 9 & Margins & As per rules \\
\hline Source: GDCR - Ahmedabad Urban Development Authority & \\
\hline
\end{tabular}




\begin{tabular}{|l|l|}
\multicolumn{2}{|c|}{$\begin{array}{c}\text { Appendix VIII: } \\
\text { Range of FSI Norm in Major Cities }\end{array}$} \\
\hline São Paulo, Brazil & $1: 1$ \\
\hline Mumbai, India & $1: 1.33$ \\
\hline Chennai, India & $1: 1.5$ \\
\hline Delhi, India & $1: 1.2-1: 3.5$ \\
\hline Amsterdam, Netherlands & $1: 1.9$ \\
\hline Venice, Italy & $1: 2.4$ \\
\hline Paris, France & $1: 3$ \\
\hline Shanghai, China & $1: 8$ \\
\hline Vancouver, Canada & $1: 8$ \\
\hline San Francisco, United States & $1: 9$ \\
\hline Chicago, United States & $1: 12$ \\
\hline Hong Kong SAR, China & $1: 12$ \\
\hline Los Angeles, United States & $1: 13$ \\
\hline New York, United States & $1: 15$ \\
\hline Denver, United States & $1: 17$ \\
\hline Tokyo, Japan & $1: 20$ \\
\hline Singapore & $1: 12-1: 25$ \\
\hline $\begin{array}{l}\text { Source: Lainton 2011, cited by World Bank Paper on Urbanisation Beyond Municipal } \\
\text { Boundaries, Chapter 3 } \\
\text { (http://elibrary.worldbank.org/doi/pdf/10.1596/9780821398401_CH03) }\end{array}$ \\
\hline
\end{tabular}

\begin{tabular}{|c|c|c|c|}
\hline \multicolumn{4}{|c|}{$\begin{array}{c}\text { Appendix IX: } \\
\text { Timeline of Statutory Approvals Typically in India }\end{array}$} \\
\hline $\begin{array}{l}\text { S. } \\
\text { No. }\end{array}$ & Activity & $\begin{array}{l}\text { Months / } \\
\text { Activity }\end{array}$ & $\begin{array}{r}\text { Cum. } \\
\text { Months }\end{array}$ \\
\hline 1 & Conversion of Land Use & $8-12$ & 12 \\
\hline 2 & $\begin{array}{l}\text { Project Letter of Intent and License / Intimation of } \\
\text { Disapproval }\end{array}$ & $4-6$ & 18 \\
\hline 3 & Pre-construction Approvals from State Level Bodies & $6-8$ & 26 \\
\hline 4 & $\begin{array}{l}\text { Pre-construction Approvals from Central Level } \\
\text { Bodies }\end{array}$ & $5-7$ & 33 \\
\hline 5 & Approvals for Construction Plan Sanction & $5-7$ & 40 \\
\hline 6 & Approvals for Commencement of Construction & $2-3$ & 43 \\
\hline 7 & Construction Period & $24-30$ & 63 \\
\hline 8 & $\begin{array}{l}\text { Inspection and Approval Procedure for Building } \\
\text { Completion }\end{array}$ & $2-3$ & 66 \\
\hline 9 & $\begin{array}{l}\text { Occupancy Certificate Receipt from date of } \\
\text { completion of above }\end{array}$ & $2-3$ & 69 \\
\hline \multicolumn{4}{|c|}{$\begin{array}{l}\text { Source: Jones Lang LaSalle, Affordable Housing in India (2012) } \\
\text { http://www.joneslanglasalle.co.in/india/en- }\end{array}$} \\
\hline
\end{tabular}


Appendix X:

Average Population Density Across States in India (in persons per sq km)

\begin{tabular}{|c|l|c|c|c|}
\hline SNo. & State & Area Sq. Km & Density 2011 & Density 2001 \\
\hline A & India (Average) & $3,287,240$ & 382 & 324 \\
\hline 1 & Cantonments & 7,130 & 293 & - \\
\hline 2 & Delhi & 1,483 & 11,320 & 9,340 \\
\hline 3 & Phandigarh & 114 & 9,258 & 7,900 \\
\hline 4 & Daman and Diu & 490 & 2,547 & 2,034 \\
\hline 5 & Lakshadweep & 311 & 2,191 & 1,413 \\
\hline 6 & Bihar & 94,163 & 2,149 & 1,895 \\
\hline 7 & West Bengal & 88,752 & 1,106 & 881 \\
\hline 8 & Kerala & 38,852 & 860 & 903 \\
\hline 9 & Uttar Pradesh & 240,928 & 829 & 819 \\
\hline 10 & Dadra and Nagar Haveli & 491 & 700 & 690 \\
\hline 11 & Haryana & 44,212 & 573 & 479 \\
\hline 12 & Tamil Nadu & 130,060 & 555 & 480 \\
\hline 13 & Punjab & 50,362 & 551 & 484 \\
\hline 14 & Jharkhand & 79,716 & 414 & 338 \\
\hline 15 & Assam & 78,438 & 398 & 340 \\
\hline 16 & Goa & 3,702 & 394 & 364 \\
\hline 17 & Maharashtra & 307,713 & 365 & 315 \\
\hline 18 & Tripura & 10,486 & 350 & 305 \\
\hline 19 & Karnataka & 191,791 & 319 & 276 \\
\hline 20 & Andhra Pradesh & 275,045 & 308 & 277 \\
\hline 21 & Gujarat & 196,244 & 308 & 258 \\
\hline 22 & Orissa & 155,707 & 270 & 236 \\
\hline 23 & Madhya Pradesh & 308,252 & 236 & 196 \\
\hline 24 & Rajasthan & 342,239 & 200 & 165 \\
\hline 25 & Uttarakhand & 53,483 & 189 & 159 \\
\hline 26 & Chhattisgarh & 135,192 & 189 & 154 \\
\hline 27 & Meghalaya & 22,429 & 132 & 103 \\
\hline 28 & Manipur & 22,327 & 128 & 103 \\
\hline 29 & Himachal Pradesh & 55,673 & 123 & 109 \\
\hline 30 & Nagaland & 16,579 & 119 & 120 \\
\hline 31 & Sikkim & 7,096 & 86 & 76 \\
\hline 32 & Jammu and Kashmir & 222,236 & 56 & 46 \\
\hline 33 & Mizoram & 21,081 & 52 & 42 \\
\hline 34 & Andaman and Nicobar Islands & 8,249 & 46 & 43 \\
\hline 35 & Arunachal Pradesh & 83,743 & 17 & 13 \\
\hline Source: Census, 2011 & & & \\
\hline http://censusindia.gov.in/2011-prov-results/data_files/india/Final_PPT_2011chapter7.pdf \\
\hline & & & & \\
\hline & & & & \\
\hline
\end{tabular}




\begin{tabular}{|c|l|c|}
\hline \multicolumn{3}{|c|}{$\begin{array}{c}\text { Appendix XI: } \\
\text { A List of Housing Policies in India }\end{array}$} \\
\hline SNo & Policy & Year of Commencement \\
\hline 1 & National Housing Policy & 1988 \\
\hline 2 & National Housing and Habitat policy & 1994 \\
\hline 3 & National Housing and Habitat Policy & 2098 \\
\hline 4 & Jawaharlal Nehru National Urban Renewal Mission & 2007 \\
\hline 5 & National Urban Housing and Habitat Policy & 2009 \\
\hline 6 & Rajiv Awas Yojana & 2015 \\
\hline 7 & Pradhan Mantri Awas Yojana: Housing for All by 2020 \\
\hline $\begin{array}{l}\text { NB: Apart from the above-mentioned policies, each of the twelve five-year plans allotted } \\
\text { specific funds to the housing needs of the country. Specifically from the seventh five-year plan } \\
\text { onwards (i.e. from 1975 onwards), urban housing shortage and slum development programmes } \\
\text { have been receiving special focus. }\end{array}$ \\
\hline
\end{tabular}




\section{REFERENCES}

Bertaud, Alain, and K. Cuenco. "Ahmedabad: Land Use Issues and Recommendations." World Bank, Washington, DC (1996).

Census of India (2011), Chapter 7: Density of Population, Govt. of India. (URL: http://censusindia.gov.in/2011-prov-results/data_files/india/Final_PPT_2011chapter7.pdf)

Clarke Annez, Patricia, Alain Bertaud, Bimal Patel, and V. K. Phatak. (2010), "Working with the market: a new approach to reducing urban slums in India. "World Bank Policy Research Working Paper Series, Vol (2010).

Department for Communities and Local Government (2010), Estimating Housing Needs, Govt of the UK.

Ghildiyal S.(2015), "Government plans to sell surplus land to ease fiscal crunch", The Times of India. (Retrieved 22.07.2015, 10.10 AM)

Govt. of AP (2016), Draft GIS Policy, Govt. of Andhra Pradesh. (Retrieved 22.02.2016, 11:40 pm) (URL: http://www.ap.gov.in/wp-

content/uploads/2016/01/AP_GIS_Policy_V3_2_Jan_16.pdf)

GP (2014), "Lessons Learned: Challenges in Formalizing the Supply of Electricity in Mumbai's Slums, The Global Partnership on Output Based Aid, Oct 2014, Note \# 6.

(http://www-

wds.worldbank.org/external/default/WDSContentServer/WDSP/IB/2014/12/08/000442464_20 141208105634/Rendered/PDF/929930BRI0P10400MumbaiElectricity01.pdf )

Gujarat Housing Board (undated), $6{ }^{\text {th }}$ CSMC Report -Affordable Housing in Partnership, Chenpur Ahmedabad, Gujarat Housing Board, Govt. of Gujarat.

Jones Lang LaSalle (2012), Affordable Housing in India, (http://www.joneslanglasalle.co.in/india/engb/Research/Affordable_Housing_in_India_2012.pdf?27e6f554-2aa8-4864-8bc39127a4b902bc).

KPMG (2014), Decoding Housing For All, KPMG.

Lainton (2011), cited by World Bank Paper on Urbanisation Beyond Municipal Boundaries, Chapter 3 (http://elibrary.worldbank.org/doi/pdf/10.1596/9780821398401_CH03)

Ministry of Defence (2015a), Press Information Bureau: New Policy Guidelines on Working on Cantonment Boards on the Anvil (20.09.2015), Govt. of India.

Ministry of Defence (2015b), Directorate General of Defence Services, (Retrieved 18.08.2015, 12:45 pm) (URL: http://www.mod.nic.in/forms/List.aspx?lid=1607\&Id=61)

Ministry of Finance (2015a), Central Plan Outlay, India Budget, Govt. of India. (Retrieved 17.08.2015; 2:05 pm) (URL: http://indiabudget.nic.in/ub2015-16/bag/bag4.pdf)

Ministry of Finance (2015b), Economic Survey 2014-15, Govt. of India. 
Ministry of Housing and Urban Poverty Alleviation (2007), National Urban Housing and Habitat Policy 2007, Govt. of India.

Ministry of Housing and Urban Poverty Alleviation (2012a) Rajiv Awas Yojana: Guidelines for Preparation of Slum-free City Plan of Action 2013-22, Govt. of India.

Ministry of Housing and Urban Poverty Alleviation (2012b) (GoI), Rajiv Awas Yojana: Scheme Guidelines 2013-22, Govt. of India.

Ministry of Housing and Urban Poverty Alleviation (2012c), (GoI), Rajiv Awas Yojana: Guidelines for Capacity Building 2013-22 (2012)

Ministry of Housing and Urban Poverty Alleviation (2012d), Report of the Task Force on Promoting Affordable Housing, Govt. of India.

Ministry of Housing and Urban Poverty Alleviation (2013), Affordable Housing in Partnership: Scheme Guidelines (2013), Govt. of India.

Ministry of Housing and Urban Poverty Alleviation (2015b), Pradhan Mantri Awas Yojana: Housing for All by 2022, Govt. of India.

Ministry of Housing and Urban Poverty Alleviation (2015c). State of Housing in India Compendium, Govt. of India.

Ministry of Urban Development and Poverty Alleviation (2015a), Mission Overview, Jawaharlal Nehru National Urban Renewal Mission, Govt. of India. (Retrieved 20.08.15, 20:35 pm) (URL: http://jnnurm.nic.in/)

Morris, Sebastian (2001), "Issues in Infrastructure Development Today - The Interlinkages" Chapter 2, of Morris, Sebastian (ed.) India Infrastructure Report 2001 - Issues in Market Structure and Regulation, 3inetwork, Oxford Univ Press. New Delhi, 2001

Morris, Sebastian and Ajay Pandey (2009), Land Markets in India: Distortions and Issues in Nirmal Mohanty, Runa Sarkar, Ajay Pandey, eds., "India Infrastructure Report 2009: Land - A Critical Resource For Infrastructure”, 3inetwork, Oxford Univ Press, New Delhi, 2009.

Morris, Sebastian, and Ajay Pandey. "Towards Reform of Land Acquisition Framework in India." Economic and Political Weekly (2007): 2083-2090.

Morris, Sebastian, and Ajay Pandey. (2010), "The Question of Land and Infrastructure Development in India: Urgently Required Reforms for Fairness and Infrastructural Development." Indian Institute of Management Working Paper 2010-03 (2010): 02. (http://papers.ssrn.com/sol3/papers.cfm?abstract_id=1755485)

National Buildings Organization (2013), State of Housing in India: A Statistical Compendium, Ministry of Housing and Urban Poverty Alleviation, Govt. of India.

NSSO (2007), Unemployment and Migration Survey (64th Round), National Sample Survey Office, Central Statistical Organisation, Govt. of India. 
Planning Commission (2013), Twelfth Five Year Plan 2012-2017, Govt. of India.

Property Rates and Trends in Ahmedabad, Sulekha (Retrieved 20.08.2015, 5:23 pm) (URL: http://property.sulekha.com/ahmedabad-real-estate-price-trend)

The Cities Alliance (2009), Social Housing in São Paulo: Challenges and New Management Tools,

(https://www.citiesalliance.org/sites/citiesalliance.org/files/CA Docs/resources/upgrading/Soci al\%20Housing\%20in\%20Sao\%20Paulo/English/Social_Housing_SaoPaulo_Eng_fulltxt.pdf )

UN Habitat (2015), Urban Themes: Housing \& Slum Upgrading, UN Habitat (Retrieved 20.08.15, 7:40 pm) (URL: http://unhabitat.org/urban-themes/housing-slum-upgrading/)

UN Population Fund (2007), State of World Population, 2007: Unleashing the Potential of Urban Growth, United Nations.

World Bank Blogs (2015): Sustainable Cities, Fernando S. Bueno and Verediana Sedeh, Improving Slums: Stories from Sao Paulo. (Retrieved 20.08.2015, 4:50 pm) (URL: http://blogs.worldbank.org/sustainablecities/no-excuses-slum-upgrading). 